\title{
FAKTOR PEMBENTUK INDEKS KEPUASAN PELAYANAN MAHASISWA DI UNIT KERJA BIRO ADMINISTRASI UMUM UNIPA SURABAYA
}

\author{
Ika Damayanti \\ Dosen Program Studi Statistika, FMIPA Universitas PGRI Adi Buana Surabaya \\ Email : ikadamayanti2012@gmail.com
}

\begin{abstract}
ABSTRAK
Salah satu cara untuk mengetahui kepuasan mahasiswa adalah dengan cara perhitungan Indeks Kepuasan Mahasiswa dalam unit-unit kerja pelayanan administrasi. Dalam penelitian Pramesti dan Damayanti (2014) yang menghitung Indeks Kepuasan Pelayanan Mahasiswa di tujuh unit kerja UNIPA, terdapat satu unit kerja yang mendapatkan nilai Indeks Cukup yaitu Biro Administrasi Umum (BAU) dengan nilai mutu 2.4675 sedangkan untuk unit kerja yang lainnya mendapatkan nilai indeks dengan mutu Baik. Melanjutkan penelitian sebelumnya, penelitian ini ditujukan untuk mengetahui variabel unsur pembentuk Indeks Kepuasan Pelayanan pada unit kerja yang mempunyai nilai mutu kurang yakni unit kerja BAU. Analisa yang digunakan adalah analisa faktor. Penelitian mengenai pelayanan di bidang pendidikan dengan metode analisis faktor antara lain dilakukan oleh Khoydairi, F., dan Khoydairi, B., (2011) yang menganalisa antara persepsi dan ekspektasi mahasiswa. Singh \& Kumar, M., (2014) juga melakukan analisis untuk mengetahui kualitas pelayanan dengan analisis faktor. Dalam penelitian ini data yang digunakan untuk sebanyak empat belas unsur pembentuk Indeks Kepuasan Pelayanan. Dari empat belas unsur pelayanan akan di analisis menjadi faktor utama yang dapat mewakili keempat belas unsure tersebut, sehingga memudahkan identifikasi peningkatan pelayanan. Berdasarkan hasil penelitian, terdapat dua faktor pembentuk indeks kepuasan pelayanan yaitu faktor Prosedur Pelayanan dan Profesionalisme Pelayanan serta Waktu Pelayanan dan Kepastian Pelayanan. Faktor 1 dengan nama Prosedur Pelayanan dan Profesionalisme Pelayanan mewakili sebelas unsure yaitu Prosedur Pelayanan, Persyaratan Pelayanan, Kejelasan Petugas Pelayanan, Kedisiplinan Petugas Pelayanan, Tanggung Jawab Petugas Pelayanan, Kemampuan Petugas Pelayanan, Keadilan Mendapatkan Pelayanan, Kesopanan dan Keramahan Petugas, Kewajaran biaya perkuliahan, Keamanan Lingkungan, Keamanan Pelayanan. Faktor 2 adalah Waktu Pelayanan dan Kepastian Pelayanan mewakili Kecepatan Pelayanan, Kepastian biaya perkuliahan, Kepastian Jadwal Pelayanan.
\end{abstract}

Kata kunci: Indeks Kepuasan Pelayanan, Mahasiswa, Analisis Faktor, Biro Administrasi Umum.

\section{Pendahuluan}

Saat ini pelayanan terhadap pelanggan merupakan salah satu pilar penting bagi sebuah institusi, tak terkecuali institusi pendidikan. Universitas PGRI Adi Buana Surabaya (UNIPA) sebagai salah satu penyelenggara pendidikan juga harus meningkatkan kualitas pelayanan terhadap pelanggannya, yakni mahasiswa. Salah satu cara untuk mengetahui kepuasan mahasiswa adalah dengan cara perhitungan Indeks Kepuasan Mahasiswa dalam unit-unit kerja pelayanan administrasi. 
Dalam penelitian Pramesti dan Damayanti (2014) yang menghitung Indeks Kepuasan Pelayanan Mahasiswa di tujuh unit kerja UNIPA terdapat satu unit kerja yang mendapatkan nilai Indeks Cukup yaitu Biro Administrasi Umum (BAU) dengan nilai mutu 2.4675, sedangkan enam unit kerja yakni BAAK, Unit LPPM, Unit Perpustakaan, Unit SPP, Unit Kemahasiswaan dan unit Fakultas berada dalam kriteria baik, yaitu dengan nilai indeksnya berada dalam interval : 2.51-3.25. Berdasarkan penelitian tersebut dapat menjadi pendorong setiap unit kerja di UNIPA untuk meningkatkan kualitas pelayanannya.

Pedoman umum untuk mengukur Indeks kepuasan mahasiswa di setiap unit pelayanan telah disusun oleh Kementrian Pendayagunaan Aparatur Negara dan Badan Pusat Statistik, yakni terdapat 14 (empat belas) unsur yang dapat diberlakukan untuk semua jenis pelayanan. Unsur-unsur tersebut disusun oleh Kementrian Pendayagunaan Aparatur Negara dan Badan Pusat Statistik berdasarkan hasil penelitian, sehingga diperoleh 14 (empat belas) unsur yang dapat diberlakukan untuk semua jenis pelayanan, untuk mengukur indeks kepuasan. Penelitian sebelumnya mengenai pelayanan di bidang pendidikan antara lain dilakukan oleh Khoydairi, F., dan Khoydairi, B., (2011) yang menganalisa antara persepsi dan ekspektasi mahasiswa mengenai pelayanan bidang pendidikan. Singh \& Kumar, M., (2014) juga melakukan analisis untuk mengetahui kualitas pelayanan dengan analisis faktor.

Hasil penelitian Pramesti \& Damayanti (2014) menunjukkan nilai indeks dari Unit Kerja BAU adalah kurang baik atau cukup. Maka untuk melanjutkan penelitian sebelumnya, tujuan dalam penelitian ini adalah mengetahui faktor pembentuk Indeks Kepuasan Pelayanan pada unit kerja BAU berdasarkan empat belas unsur. Sehingga dapat diidentifikasi faktor apa sajakah yang perlu di tingkatkan pada pelayanan unit kerja BAU agar indeks kepuasan pelayanan semakin meningkat.

\section{Metodologi Penelitian}

\subsection{Variabel Penelitian}

Data penelitian ini diambil dari penelitian sebelumnya oleh Pramesti dan Damayanti (2014). Data yang diteliti adalah untuk Unit Kerja Biro Administrasi Umum. Variabel dalam penelitian ini adalah unsur-unsur indeks kepuasan mahasiswa sebagai berikut :

1. Prosedur Pelayanan $\left(X_{1}\right)$

2. Persyaratan Pelayanan $\left(X_{2}\right)$

3. Kejelasan Petugas Pelayanan $\left(X_{3}\right)$

4. Kedisiplinan Petugas Pelayanan $\left(X_{4}\right)$

5. Tanggung Jawab Petugas Pelayanan $\left(X_{5}\right)$

6. Kemampuan Petugas Pelayanan $\left(X_{6}\right)$

7. Kecepatan Pelayanan $\left(X_{7}\right)$

8. Keadilan Mendapatkan Pelayanan $\left(X_{8}\right)$

9. Kesopanan dan Keramahan Petugas $\left(X_{9}\right)$

10. Kewajaran biaya perkuliahan $\left(X_{10}\right)$ 
11. Kepastian biaya perkuliahan $\left(X_{11}\right)$

12. Kepastian Jadwal Pelayanan $\left(X_{12}\right)$

13. Keamanan Lingkungan $\left(X_{13}\right)$

14. Keamanan Pelayanan $\left(X_{14}\right)$

\subsection{Analisa Faktor}

Analisa faktor digunakan untuk menggambarkan hubungan korelasi dari beberapa variabel dalam jumlah kecil faktor. Variabel-variabel ini dapat dikelompokkan menjadi beberapa faktor, dimana variabel-variabel dalam suatu faktor mempunyai korelasi yang tinggi sedangkan korelasi dengan variabelvariabel pada faktor lain relatif rendah.

Uji kecukupan sampel, dengan menggunakan Kaiser-Mayer-Olkin (KMO) yang merupakan suatu indeks untuk membandingkan kesesuaian koefisien korelasi observasi dengan koefisien korelasi parsial, akan dapat dinyatakan sampel yang ada sudah mencukupi kelayakan untuk diolah dengan metode analisa faktor (Kaiser, 1970). Secara matematis hal ini dapat ditulis:

$$
\mathrm{KMO}=\frac{\sum_{i \neq j} \sum_{i j}^{2}}{\sum \sum r_{i j}^{2}+\sum_{i \neq j} \sum a_{i j}^{2}}
$$

dimana : $r_{i j}=$ koefisien korelasi antara variabel $\mathrm{i}$ dan $\mathrm{j}$

$a_{i j}=$ koefisien korelasi parsial antara variabel i dan $\mathrm{j}$

Jika jumlah kuadrat koefisien korelasi parsial diantara seluruh pasangan variabel-variabel tersebut kecil terhadap jumlah kuadrat koefisien korelasi, maka harga KMO mendekati satu. Harga KMO kecil merupakan indikator bahwa analisis faktor terhadap variabel-variabel tersebut tidak sesuai, karena korelasi diantara variabel tidak dapat dijelaskan oleh variabel lain. Shubash Sharma (1996) menetapkan karakteristik pengukuran bahwa nilai KMO sebesar 90\% adalah sangat bagus, nilai $80 \%$ bagus, $70 \%$ cukup, $60 \%$ kurang, $50 \%$ jelek dan dibawah $50 \%$ tidak dapat diterima atau dikatakan analisis faktor tidak sesuai untuk variabel-variabel tersebut dan hasilnya akan kurang bermanfaat.

Pada dasarnya analisa faktor bertujuan untuk mendapatkan sejumlah kecil faktor dengan anggapan bahwa setiap variabel asal dapat dinyatakan sebagai kombinasi linier dari faktor-faktor itu ditambah dengan suku residualnya dan memiliki sifat-sifat sebagai berikut :

1. Mampu menerangkan semaksimal mungkin keragaman data.

2. Faktor - faktor saling bebas.

3. Setiap faktor dapat diinterpretasikan. 


\section{Hasil dan Pembahasan}

Berikut diberikan hasil perhitungan Indeks Kepuasan Pelayanan berdasarkan penelitian sebelumnya. Berdasarkan perhitungan nilai Indeks Kepuasan Mahasiswa, dari tujuh Unit Kerja yang diteliti hampir semuanya dalam kriteria baik. Satu unit yang mendapat penilaian Cukup adalah unit kerja BAU (Biro Administrasi Umum).

Tabel 4.1 Hasil Perhitungan Tabel Persepsi, Konversi IKM, Mutu dan Kinerja Unit

\begin{tabular}{|l|c|c|c|c|}
\hline \multicolumn{1}{|c|}{ Unit } & $\begin{array}{c}\text { Interval } \\
\text { IKM }\end{array}$ & $\begin{array}{c}\text { Interval } \\
\text { Konversi }\end{array}$ & $\begin{array}{c}\text { Mutu } \\
\text { Pelayanan }\end{array}$ & Kinerja Unit \\
\hline BAU & 2.4675 & 61.68831 & $\mathrm{C}$ & Cukup \\
\hline BAAK & 2.5206 & 63.01407 & $\mathrm{~B}$ & Baik \\
\hline SPP & 2.5265 & 63.16288 & $\mathrm{~B}$ & Baik \\
\hline PERPUSTAKAAN & 2.6943 & 67.3566 & $\mathrm{~B}$ & Baik \\
\hline LP2M & 2.6607 & 66.51786 & $\mathrm{~B}$ & Baik \\
\hline KEMAHASISWAAN & 2.6780 & 66.95076 & $\mathrm{~B}$ & Baik \\
\hline FAKULTAS & 2.7154 & 67.8842 & $\mathrm{~B}$ & Baik \\
\hline
\end{tabular}

*sumber : Hasil Penelitian Pramesti dan Damayanti (2014)

Sebelum dilakukan analisa faktor langkah pertama adalah menguji kecukupan sampel dengan menggunakan uji Bartlett dan Kaiser-Mayer-Olkin $(K M O)$, hasilnya adalah sebagai berikut :

Tabel 4.2 Uji Bartlett dan KMO

\begin{tabular}{|c|c|}
\hline \multicolumn{2}{|c|}{ Uji Bartlett dan KMO } \\
\hline Ukuran kecukupan sampel KMO & 0.876 \\
\hline Uji Bartlett angka Chi-Square & 642.302 \\
\hline Signifikansi & 0.000 \\
\hline
\end{tabular}

Dari hasil uji Bartlett dan KMO diatas diperoleh nilai ukuran kecukupan sampel (MSA) sebesar 0.876, karena nilai tersebut lebih besar dari 0.5 maka variabel-variabel persepsi kepuasan tersebut dapat dianalisa lebih lanjut. Ini juga dapat dilihat dari uji Bartlett yang ditampilkan oleh nilai Chi-Square dengan nilai signifikansi .000. Langkah selanjutnya adalah memilih variabel yang akan masuk dalam analisa faktor, pemilihan dilakukan dengan melihat anti image matrice yaitu : 
Tabel 4.3 Pemilihan Variabel

\begin{tabular}{|l|l|c|}
\hline No. & Unsur Pelayanan & Nilai MSA \\
\hline 1. & Prosedur Pelayanan & 0.815 \\
\hline 2. & Persyaratan Pelayanan & 0.848 \\
\hline 3. & Kejelasan Petugas Pelayanan & 0.918 \\
\hline 4. & Kedisiplinan Petugas Pelayanan & 0.900 \\
\hline 5. & Tanggung Jawab Petugas Palayanan & 0.859 \\
\hline 6. & Kemampuan Petugas Pelayanan & 0.873 \\
\hline 7. & Kecepatan Petugas Pelayanan & 0.815 \\
\hline 8. & Keadilan mendapatkan Pelayanan & 0.906 \\
\hline 9. & Kesopanan dan Keramahan Petugas & 0.890 \\
\hline 10. & Kewajaran Biaya Pelayanan & 0.881 \\
\hline 11. & Kepastian Biaya Pelayanan & 0.853 \\
\hline 12. & Kepastian Jadwal Pelayanan & 0.900 \\
\hline 13. & Kenyamanan Lingkungan & 0.840 \\
\hline 14. & Keamanan Pelayanan & 0.926 \\
\hline
\end{tabular}

Dari tabel diatas terlihat bahwa tidak ada variabel yang mempunyai nilai ukuran kecukupan sampel (MSA) kurang dari 0.5. Maka selanjutnya dilakukan analisa faktor dengan memasukkan seluruh variabel. Setelah proses pemilihan variabel selesai selanjutnya adalah melihat hubungan dengan faktor yang nantinya terbentuk. Untuk lebih jelasnya dapat dilihat dari tabel matrik komunalitas sebagai berikut :

Tabel 4.4 Matrik Komunalitas

\begin{tabular}{|l|l|r|}
\hline No. & \multicolumn{1}{|c|}{ Unsur Pelayanan } & $\begin{array}{c}\text { Nilai } \\
\text { Ekstraksi }\end{array}$ \\
\hline 1. & Prosedur Pelayanan & .475 \\
\hline 2. & Persyaratan Pelayanan & .575 \\
\hline 3. & Kejelasan Petugas Pelayanan & .551 \\
\hline 4. & Kedisiplinan Petugas Pelayanan & .486 \\
\hline 5. & Tanggung Jawab Petugas Palayanan & .449 \\
\hline 6. & Kemampuan Petugas Pelayanan & .490 \\
\hline 7. & Kecepatan Petugas Pelayanan & .358 \\
\hline 8. & Keadilan mendapatkan Pelayanan & .531 \\
\hline 9. & Kesopanan dan Keramahan Petugas & .439 \\
\hline 10. & Kewajaran Biaya Pelayanan & .469 \\
\hline 11. & Kepastian Biaya Pelayanan & .619 \\
\hline 12. & Kepastian Jadwal Pelayanan & .555 \\
\hline 13. & Kenyamanan Lingkungan & .400 \\
\hline 14. & Keamanan Pelayanan & .425 \\
\hline
\end{tabular}

Dari tabel diatas untuk variabel prosedur pelayanan diperoleh nilai ekstraksi sebesar 0.475. Ini berarti sekitar $47.5 \%$ varians dari variabel prosedur pelayanan dapat dijelaskan oleh faktor yang nanti akan terbentuk. Demikian juga untuk unsur persyaratan pelayanan diperoleh nilai 0.575 yang berarti $57.5 \%$ 
varians unsur Persyaratan pelayanan dapat dijelaskan oleh faktor yang akan terbentuk, demikian seterusnya untuk variabel yang lain. Untuk variabel yang mempunyai nilai ekstraksi kecil maka hubungannya dengan faktor yang terbentuk semakin lemah.

Selanjutnya untuk mengetahui besarnya keragaman data yang dapat menerangkan faktor yang nantinya terbentuk, dapat dilihat pada tabel di bawah.

Tabel 4.5 Nilai Eigen

\begin{tabular}{|c|r|r|r|}
\hline \multirow{2}{*}{ FAKTOR } & \multicolumn{3}{|c|}{ NILAI EIGEN } \\
\hline 1. & 5.703 & 40.736 & \% \\
\hline 2. & 1.120 & 7.997 & 40.736 \\
\hline 3. & .980 & 6.997 & 58.734 \\
\hline 4. & .918 & 6.559 & 62.731 \\
\hline 5. & .837 & 5.975 & 68.265 \\
\hline 6. & .738 & 5.268 & 73.533 \\
\hline 7. & .654 & 4.673 & 78.206 \\
\hline 8. & .595 & 4.247 & 82.453 \\
\hline 9. & .546 & 3.900 & 86.353 \\
\hline 10. & .504 & 3.597 & 89.950 \\
\hline 11. & .465 & 3.321 & 93.272 \\
\hline 12. & .378 & 2.703 & 95.974 \\
\hline 13. & .296 & 2.112 & 98.087 \\
\hline 14. & .268 & 1.913 & 100.000 \\
\hline
\end{tabular}

Dari tabel diatas diperoleh 2 faktor yang mampu menerangkan keragaman data sebesar 48.734\%, hal ini dapat dilihat dari nilai eigen yang lebih besar dari 1 . Sehingga dari sini dapat diketahui bahwa dari 14 variabel unsur pelayanan asal yang ada dapat dinyatakan oleh 2 faktor baru yang menerangkan keragaman data sebesar $48.734 \%$.

Untuk memudahkan interpretasi dilakukan rotasi tegak lurus varimax. Dipilih rotasi tegak lurus varimax karena dengan rotasi varimax akan dapat memaksimalkan variansi data sehingga hasil analisa faktor akan lebih mudah diinterpretasikan. Hasil pengelompokan dapat dilihat pada tabel dibawah ini : 
Tabel 4.6 Matriks Rotasi

\begin{tabular}{|l|l|l|}
\hline \multirow{2}{*}{} & \multicolumn{2}{|c|}{ Component } \\
\cline { 2 - 3 } & \multicolumn{1}{|c|}{1} & \multicolumn{1}{|c|}{2} \\
\hline u1 & .688 & .048 \\
u2 & .739 & .169 \\
u3 & .712 & .209 \\
u4 & .665 & .208 \\
u5 & .596 & .307 \\
u6 & .655 & .247 \\
u7 & .253 & .543 \\
u8 & .586 & .433 \\
u9 & .569 & .341 \\
u10 & .512 & .455 \\
u11 & .044 & .785 \\
u12 & .188 & .721 \\
u13 & .622 & .112 \\
\hline u14 & .506 & .411 \\
\hline
\end{tabular}

Berdasarkan tabel matriks rotasi diperoleh pengelompokan variabel unsur pelayanan seperti berikut ini :

Tabel 4.7 Pengelompokan Variabel

\begin{tabular}{|c|c|c|}
\hline FAKTOR & VARIABEL UNSUR PELAYANAN & NAMA FAKTOR \\
\hline Faktor 2 & $\begin{array}{l}\text { Prosedur Pelayanan }\left(X_{1}\right) \\
\text { Persyaratan Pelayanan }\left(X_{2}\right) \\
\text { Kejelasan Petugas Pelayanan }\left(X_{3}\right) \\
\text { Kedisiplinan Petugas Pelayanan }\left(X_{4}\right) \\
\text { Tanggung Jawab Petugas Pelayanan }\left(X_{5}\right) \\
\text { Kemampuan Petugas Pelayanan }\left(X_{6}\right) \\
\text { Keadilan Mendapatkan Pelayanan }\left(X_{8}\right) \\
\text { Kesopanan dan Keramahan Petugas }\left(X_{9}\right) \\
\text { Kewajaran biaya perkuliahan }\left(X_{10}\right) \\
\text { Keamanan Lingkungan }\left(X_{13}\right) \\
\text { Keamanan Pelayanan }\left(X_{14}\right) \\
\text { Kecepatan Pelayanan }\left(X_{7}\right) \\
\text { Kepastian biaya perkuliahan }\left(X_{11}\right) \\
\text { Kepastian Jadwal Pelayanan }\left(X_{12}\right)\end{array}$ & $\begin{array}{c}\text { Waktu } \\
\text { Pelayanan dan } \\
\text { Kepastian } \\
\text { Pelayanan }\end{array}$ \\
\hline
\end{tabular}

Dari tabel diatas dapat dijelaskan faktor-faktor yang terbentuk dari variabel unsur pembentuk indeks kepuasan pelayanan sebagai berikut :

- Faktor 1 dengan nama Prosedur Pelayanan dan Profesionalisme Pelayanan mewakili sebelas unsure yaitu Prosedur Pelayanan, Persyaratan Pelayanan, Kejelasan Petugas Pelayanan, Kedisiplinan 
Petugas Pelayanan, Tanggung Jawab Petugas Pelayanan, Kemampuan Petugas Pelayanan, Keadilan Mendapatkan Pelayanan, Kesopanan dan Keramahan Petugas, Kewajaran biaya perkuliahan, Keamanan Lingkungan, Keamanan Pelayanan.

- Faktor 2 adalah Waktu Pelayanan dan Kepastian Pelayanan mewakili Kecepatan Pelayanan, Kepastian biaya perkuliahan, Kepastian Jadwal Pelayanan.

\section{Kesimpulan}

a. Berdasarkan hasil penelitian, terdapat dua faktor pembentuk indeks kepuasan pelayanan yaitu faktor Prosedur Pelayanan dan Profesionalisme Pelayanan serta Waktu Pelayanan dan Kepastian Pelayanan.

b. Faktor 1 dengan nama Prosedur Pelayanan dan Profesionalisme Pelayanan mewakili sebelas unsure yaitu Prosedur Pelayanan, Persyaratan Pelayanan, Kejelasan Petugas Pelayanan, Kedisiplinan Petugas Pelayanan, Tanggung Jawab Petugas Pelayanan, Kemampuan Petugas Pelayanan, Keadilan Mendapatkan Pelayanan, Kesopanan dan Keramahan Petugas, Kewajaran biaya perkuliahan, Keamanan Lingkungan, Keamanan Pelayanan. Faktor 2 adalah Waktu Pelayanan dan Kepastian Pelayanan mewakili Kecepatan Pelayanan, Kepastian biaya perkuliahan, Kepastian Jadwal Pelayanan.

\section{Daftar Pustaka}

Firoozkooh Branch, Behnaz Khodayar, (2011), Service Quality in Higher Education, Interdisciplinary Journal of Research in Business Vol. 1, Issue. 9, (pp.38-46).

----------------, 1998, Deregulasi Denirokratisasi dalam Upaya Peningkatan Pelayanan Masyarakat, dalam Pembangunan Administrasi di Indonesia, Pusata LP3ES Jakarta.

Pramesti, W., dan Damayanti, I., 2014, Indeks Kepuasan Mahasiswa Terhadap Penyelenggara Pendidikan (UNIPA), Hibah Kompetisi Penelitian Adi Buana 2014 .

Sharma, S., (1976), Applied Multivariate Technique, John Wiley and Sons, New York.

Singh, G., \& Kumar M., (2014), Exploratory Factor Analysis of Service Quality Dimensions for Higher Educational Institutes : A students perspective, Global Journal of Management and Business ResearchVolume 14 issue 8 version 1.0 year 2014, India.

Undang-Undang RI No. 25 Tahun 2009 tentang Pelayanan Publik.

Kepmenpan No 25 Tahun 2004 tentang pedoman umum penyusunan Indeks kepuasan masyarakat dan unit pelayanan instansi pemerintah.

Kepmenpan No 63 Tahun 2003 tentang pedoman penyelenggaraan pelayanan umum. 